\begin{tabular}{l|l|l|} 
CRITICAL & $\begin{array}{l}\text { Western Ghats } \\
\text { PARTNERSHIP FUND }\end{array}$ & Special Series \\
\hline
\end{tabular}

\title{
WEATHER-INDUCED MASS DEATHS OF THE COMMON HOUSE SWIFT Apus afFinis IN THENGUMARAHADA Village Of THE NilgiRIS, SOUTHERN INDIA
}

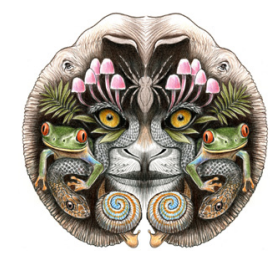

ISSN

Online 0974-7907 Print 0974-7893

OPEN ACCESS

\section{B. Ramakrishnan ${ }^{1}$, G. Sivasubramanian ${ }^{2}$, K. Ramkumar ${ }^{3} \&$ S. Ramasubramanian ${ }^{4}$}

\author{
${ }^{1}$ Assistant Professor of Wildlife Biology, Department of Zoology \& Wildlife Biology, Government Arts College, \\ Udhagamandalam, Tamil Nadu 643002 India \\ 2 Senior Project Officer, Nilgiris \& Eastern Ghats Landscape Programme, WWF-India, Coimbatore, Tamil Nadu, India \\ ${ }^{3}$ Senior Field Officer, Wildlife Trust of India, Noida 201301 India \\ ${ }^{4}$ District Forest Officer, Sathyamangalam Forest Division, Gobi Road, Sathyamangalam Post, Erode District, Tamil Nadu \\ 638401 India \\ ${ }^{1}$ bio.bramki@gmail.com (corresponding author), ${ }^{2}$ sisu.wwf@gmail.com, ${ }^{3}$ ramkumar@wti.org.in, \\ ${ }^{4}$ uma_rama@mailcity.com
}

\begin{abstract}
Weather influences all living organisms, especially wild animals. In the case of birds, inclement weather conditions may affect them during migration and feeding that could cause mass mortality in the same species or many related species. This paper describes an incidence of mass deaths of the Common House Swift Apus affinis at Thengumarahada Village of Nilgiris, Tamil Nadu, southern India during February 2008. The samples of the dead birds were sent for toxicological and bacteriological examination at Southern Regional Disease Diagnostic Laboratory, Bangalore. Spot post mortems were also conducted by forest veterinarians. Results of the diagnostic analysis revealed that mass mortality might be due to extreme weather conditions leading to acute dehydration, shock and death. The postmortem reports say that the crop and the gastro intestina tract (GI) were found empty in all the cases, suggesting starvation. We thus conclude that unseasonal heavy rains and non availability of food could have led to hypothermia and starvation of birds over a long period resulting in mass mortality.
\end{abstract}

Keywords: Apus affinis, hypothermia, mass death, starvation, weather
Climate change in response to global warming is one of the determining factors in the conservation of wildlife in the present scenario. Living organisms occupy niche habitats within a major ecosystem according to their biological requirements. The micro climatic conditions prevailing within the ecological niche are responsible for the survival of living organisms. Any abnormal variation in the weather condition is likely to affect the survival of the native species in their habitats. In the case of birds, inclement weather conditions can affect the feeding activities and can cause mass mortality owing to starvation (Newton 2007). Especially, for insectivorous bird species, a sufficient quantity and accessibility of food is very crucial, which in turn depends on favorable

DOI: http://dx.doi.org/10.11609/JoTT.o3405.5273-6 | ZooBank: urn:Isid:zoobank.org:pub:907FA4EF-E8DC-4C68-83BD-35FD9D42F86C

Editor: V. Santharam, Institute of Bird Studies \& Natural History, Chittoor, India.

Date of publication: 26 December 2013 (online \& print)

Manuscript details: Ms \# 03405 | Received 10 November 2012 | Final received 02 December 2013 | Finally accepted 04 December 2013

Citation: Ramakrishnan, B., G. Sivasubramanian, K. Ramkumar \& S. Ramasubramanian (2013). Weather-induced mass deaths of the Common House Swift Apus affinis in Thengumarahada Village of the Nilgiris, southern India. Journal of Threatened Taxa 5(17): 5273-5276; http://dx.doi.org/10.11609/JoTT.o3405.5273-6

Copyright: @ Ramakrishnan et al. 2013. Creative Commons Attribution 3.0 Unported License. JoTT allows unrestricted use of this article in any medium, reproduction and distribution by providing adequate credit to the authors and the source of publication.

Funding: None.

Competing Interest: None.

Acknowledgements: We are deeply indebted to the veterinary experts Dr. N.S. Manoharan, Forest Veterinary Officer, Dr. N. Kalaivanan, Forest Veterinary Assistant Surgeon, Tamil Nadu Forest Department, Dr. R. Chandrasekaran, Assistant Director, Dr. Kasthuri and Dr. Yuvaraj, Veterinary Assistant Surgeons, Animal Disease Intelligence Unit, Udhagamandalam for their kind help in sharing the post mortem reports and laboratory results of the dead birds. We are thankful to Mr. G. Kannan, Biologist, Indian Institute of Science, Masinagudi for providing photographs (3 \& 4) for this article. We are thankful to Mr. Soundrapandian, IFS, District Forest Officer, Nilgiris North Forest Division, for rendering his cooperation during the field observation. Our sincere thanks to Dr. C. Arivazhagan, Conservation Biologist, Care Earth for his immense help in various ways to complete this manuscript.

The publication of this article is supported by the Critical Ecosystem Partnership Fund (CEPF), a joint initiative of I'Agence Française de Développement, Conservation International, the European Commission, the Global Environment Facility, the Government of Japan, the MacArthur Foundation and the World Bank. 
climatic conditions (Rajchard et al 2006). Insectivorous birds, especially swifts and similar aerial feeding birds are extremely sensitive to weather conditions (Martins \& Wright 1993). There were many reports on such weather-induced mass bird deaths around the world (see http://home.att.net/ thehessians/birds.html).

This paper describes one such phenomenon of mass deaths of the Common House Swift Apus affinis in Thengumarahada Village of the Nilgiris District of Tamil Nadu in southern India. The Common House Swift is a smoky-black bird with a prominent white throat and rump and belongs to the order Apodiformes. It is a common breeding resident and has a wide range of distribution, often associated with human habitations and usually shelters in old buildings, forts, etc (Ali \& Ripley 1987). It has also been listed as 'Least Concern' in the Threatened Birds of the World (Birdlife International 2008; IUCN 2007). Swifts are generally seen in large flocks spending most of their time feeding on insects while in flight and take rest only at night.

\section{Study area}

The Thengumrahada Village lies between 76054'34"$76^{0} 56^{\prime} 0.8^{\prime \prime} \mathrm{N} \& 11^{0} 33^{\prime} 19^{\prime \prime}-11^{0} 34^{\prime} 40^{\prime \prime} \mathrm{E}$ and is situated amidst Nilgiri Eastern Slope Reserve Forest (Fig. 1). About 500 acres of land in this village was leased out to 141 families of the Badaga community, people of the Nilgiris, to cultivate grains under "grow more food" campaign in the early 1950s. Crops such as Rice Oryza sativa, Maize Zea mays, Ragi Elusine coracana and Groundnut Arachis hypogea are being cultivated in this village every year. Many insectivorous birds are attracted every year towards the agricultural lands of this village due to huge congregations of insects during the harvest period. Normally, paddy is harvested between January and February when there is less chance of heavy rainfall.

\section{Methods}

From 12 to 14 February 2008, we recorded mass deaths of Apus affinis (1000+ dead birds) in and around Thengumarahada Village immediately after heavy
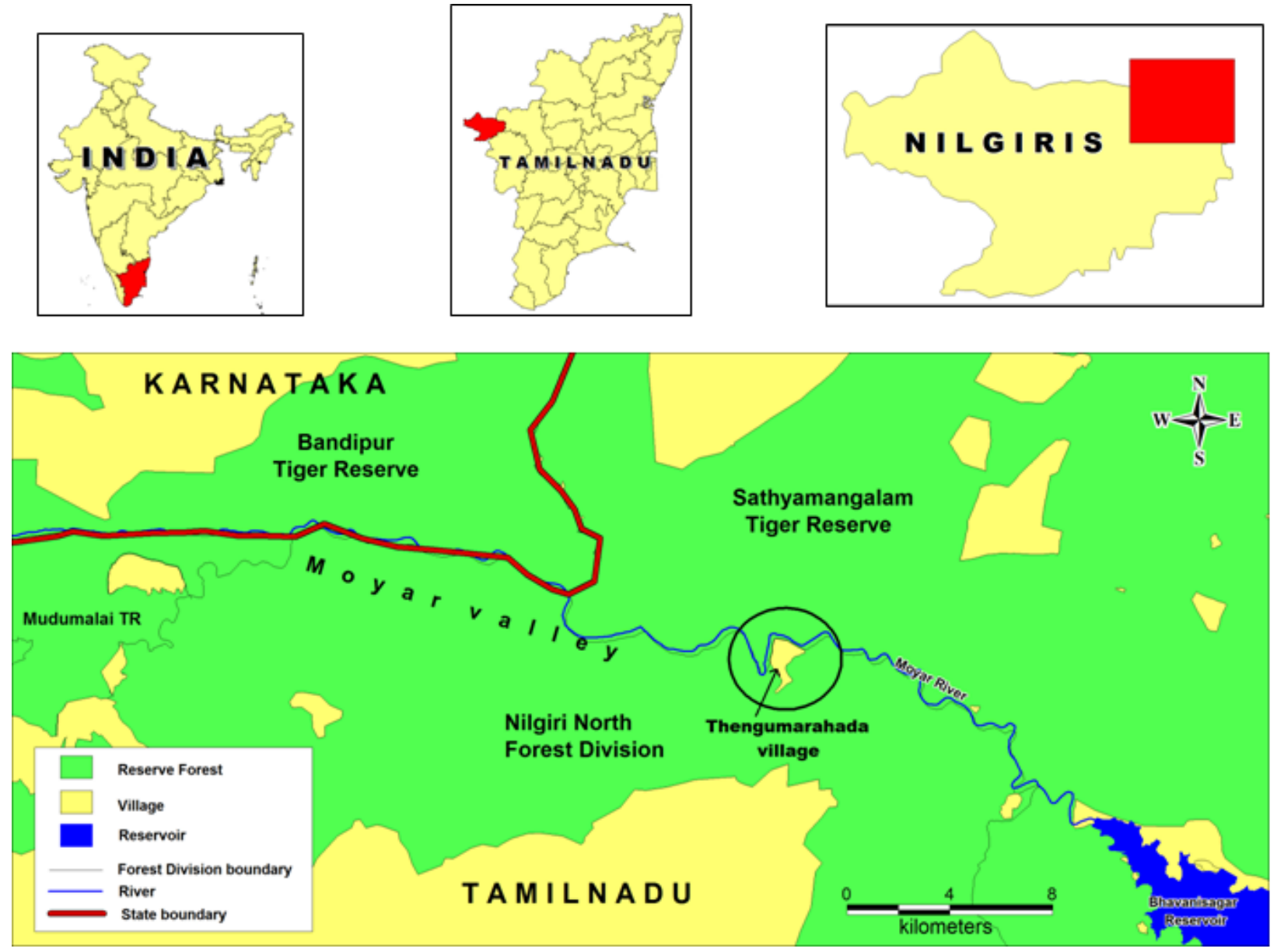

Figure 1. Location of Thengumarahada Village. 
continuous rains. Pooled samples of the dead birds were sent to the Institute of Animal Health and Veterinary Biologicals, Southern Regional Disease Diagnostic Laboratory, Bangalore (SRDDL) on 15 February 2008 for toxicological and bacteriological examinations. Spot post mortems were also conducted jointly by the forest, local and district animal disease intelligence unit veterinarians. Rainfall data was collected from 20012008 for Thengumarahada Village from Public Works Department, Government of Tamil Nadu.

\section{Results}

The final diagnostic result from SRDDL was received on 22 February 2008 stating that the tissue samples (lung/liver/heart/others) did not reveal growth of any specific etiological pathogens, that the pooled samples of intestinal, stomach contents, liver and kidneys were found negative for hydrocynide/zinc phosphide/organo phosphorus compounds (OPC). The laboratory diagnosis result finally concluded that the mass mortality might be due to extreme weather conditions leading to acute dehydration, shock and death (for details see Appendix 1).

Since the laboratory results were negative, we switched focus to the spot postmortem examinations. The postmortem results revealed that the crop and the gastro-intestinal tracts (GI) were empty in all cases, suggesting starvation. Besides, congestion of liver and kidney, viscous blood, pale and dry mucous membrane and loss of fat reserves were also noticed (Images 1-4). The plumage of the birds was completely wet and intertwined with mud. The above-mentioned observations revealed that death was caused due to starvation and stress. The chicks and juveniles had not fed for three days due to unavailability of food caused by heavy rains.

Within three days (12-14 Feburay 2008), about $200 \mathrm{~mm}$ rainfall was recorded which is quite unusual for this area compared to the past few years (2001-2007) (Fig. 2). Flash floods were noticed in the nearby jungle streams. The dead birds were seen floating and the feathers were coated with muddy water. Most of the dead birds (nearly 80\%) were chicks and juveniles.

\section{Discussion}

Thengumarahada Village is in the rain shadow area which receives rainfall from the northeast monsoon (September to November). From the records of the past few years it is clear that this area receives rain from September to November. The unusual rainfall noticed in the month of February 2008, may be the cause for the

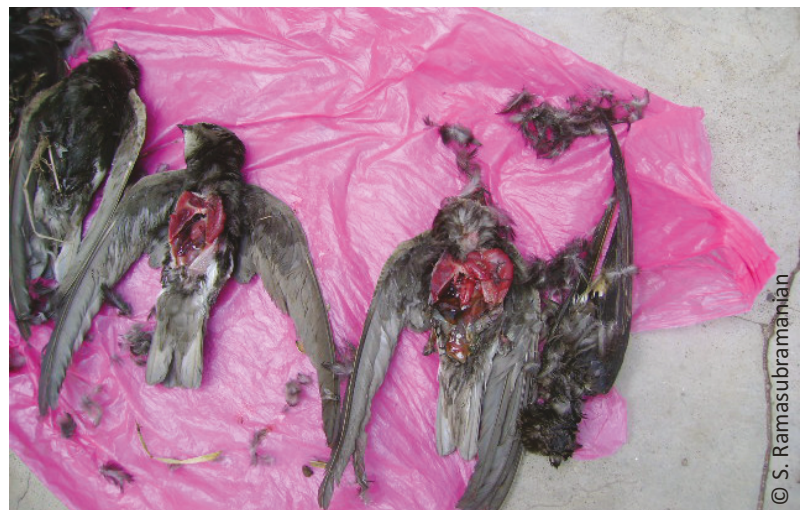

Image 1. Spot postmortems were conducted on some birds

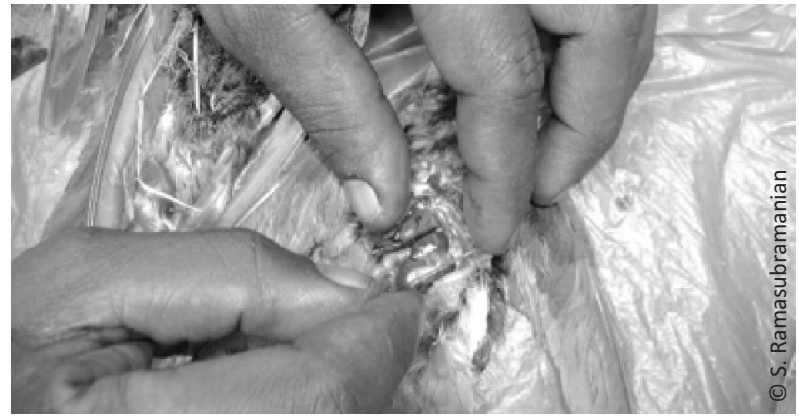

Image 2. Dead birds, mainly chicks and juveniles' crops and Intestinal tracts were found empty

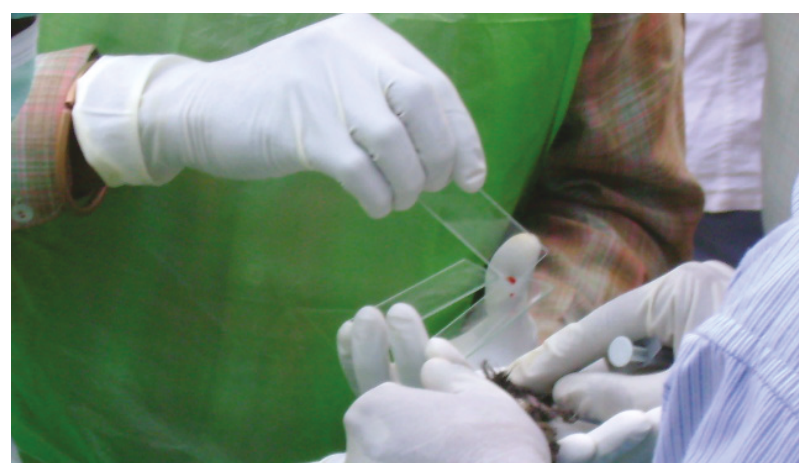

Image 3. Veterinary experts undertook spot postmortem and collected samples

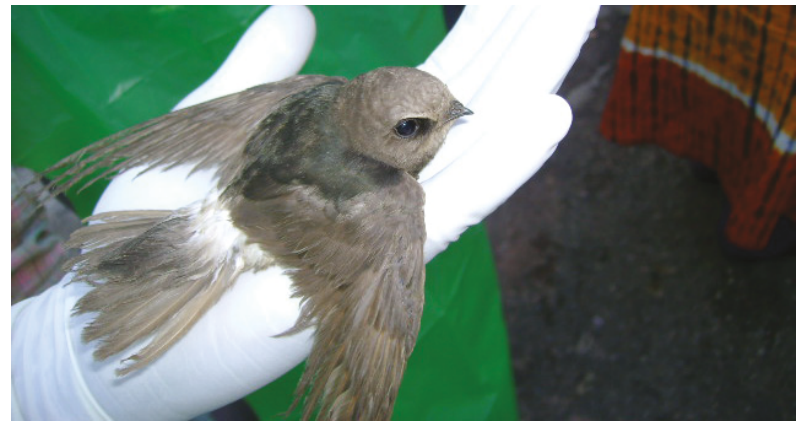

Image 4. Some of the live birds were collected and dried to facilitate flight 


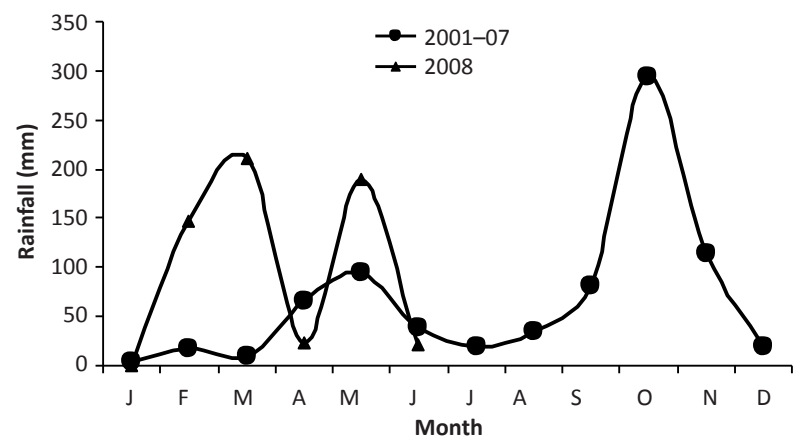

Figure 1. Rain fall status recorded for Thengumarahada Village from 2001 to 2008. (Source: Public Works Department, Govt. of Tamil Nadu)

mass deaths of the species. Food being scarce in the forest, they would move to near-by agricultural fields for foraging. The Common House Swift is an aerial feeder, predominantly dependent on winged insects. Owing to the heavy rains, insects may have became dormant and the birds were without food for three days. We did not find a single dead specimen in the natural forest areas. Our observation continued for three days from 12-14 February 2008. This present observation corroborates with previous sporadic incidents that occurred around the world. Bull \& Dawson (1969) stated that a total 810 birds belonging to 13 species were found dead during a three-day visit in South Canterbury due to a severe and unseasonal snow-storm. They also recorded an absence of dead birds in native forest areas. Avery et al. (1977) found that cloud cover and wind directions were the reasons for the mortality of many nocturnal birds in a North Dakota Tower, he recorded that 48 birds were found dead on 4 and 5 October 1972 due to overcast skies, and northeastern wind of $5-15 \mathrm{~km} / \mathrm{hr}$, followed by 69 birds found dead due to overcast skies, and light rain on 25 and 26 September 1973.

This present observation indicates that heavy rain and non availability of food could have led to the starvation of the birds. Due to starvation they were not able to fly in the rain. Subsequently, these birds drowned as the storm water added more weight. Also the heavy rain saturated the plumage and increased the wing weight causing a loss of body heat (Newton 2007). After the rain, some of the live birds were collected by the study team and their wings were dried and they were allowed to fly. Most of them took off and continued to survive after getting the necessary warmth.

The present observation concluded that the mass death of birds was due to hypothermia and starvation. This incident sheds light on the need for detailed studies of such incidents in the light of climate change effects.

\section{REFERENCES}

Ali, S., \& D. Ripley (1983). Handbook of the birds of India and Pakistan. Complete edition, Oxford University Press, Bombay.

Avery, M., P.F. Springer, \& J.F. Cassel (1977). Weather influences on nocturnal bird mortality at a North Dakota Tower. The Wilson Bulletin 89(2): 291-299.

Birdlife International (2008). Species fact sheet: Apus affinis. Down loaded from <http://www.birdlife.org> Downloaded on 30 July 2008

Bull, P.C. \& D.G. Dawson (1969). Mortality and survival of birds during an unseasonable snow-storm in South Canterbury November 1967. Notornis (Quarterly Journal of the Ornithological Society of New Zealand) 16(3): 172-179.

IUCN (2007). IUCN Red List of Threatened Species <www.iucnredlist. org>. Downloaded on 30 July 2008.

Martins, T.L.F. \& J. Wright (1993). Patterns of food allocation between parent and young under differing weather condition in the Common Swift Apus apus. Avocetta 17: 147-156.

Newton, I. (2007). Weather related mass-mortality events in migrants. Ibis 149: 453-467.

Rajchard, J., J. Prochazk \& P. Kindlmann (2006). Long-term decline in Common Swift Apus apus annual breeding success may be related to weather condition. Ornis Fernnica. 83: 66-72.

Appendix 1.
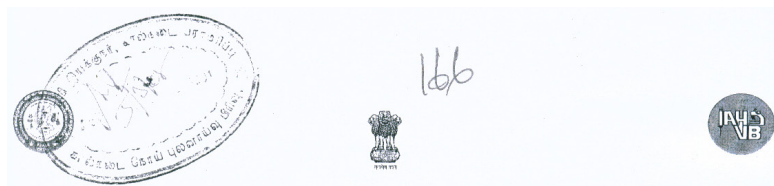

PHONE-23515882/23411502/2341166 Email- jdsrddI@rediffmail.com INSTITUTE OF ANIMAL HEALTH AND VETERINARY BIOLOGICALS SOUTHERN REGIONAL DISEASE DIAGNOSTIC LABORATORY HEBBAL, BANGALORE - 560024 FINAL DISEASE INVESTIGATION REPORT

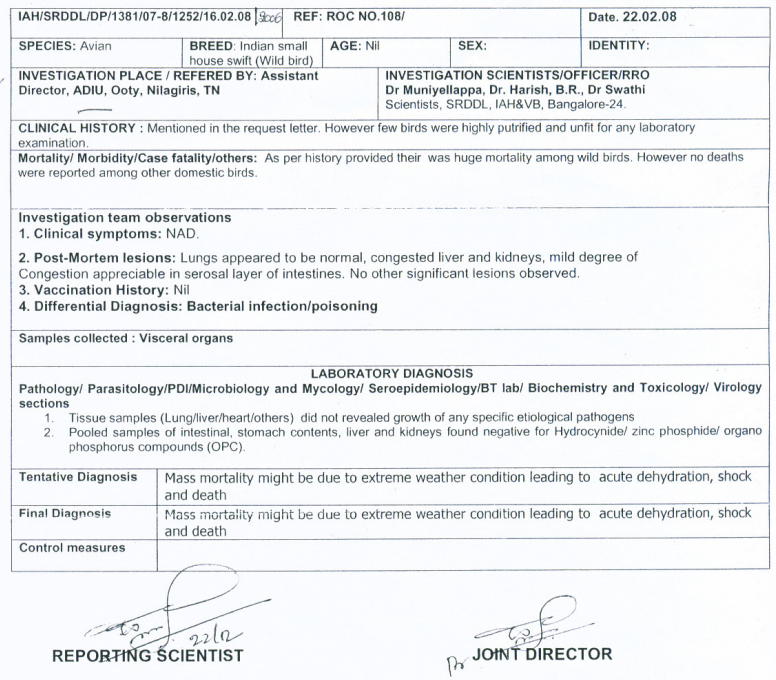

REPORTING SCIENTIST

POINT DIRECTOR 